\title{
R\&D of Photovoltaic Thermal (PVT) Systems: an Overview
}

\author{
Ahmad Fudholi ${ }^{1}$, Kamaruzzaman Sopian ${ }^{2}$ \\ Solar Energy Research Institute, Universiti Kebangsaan Malaysia, 43600 Bangi Selangor, Malaysia
}

\begin{tabular}{l} 
Article Info \\
\hline Article history: \\
Received Dec 19, 2017 \\
Revised Jan 18, 2018 \\
Accepted Feb 3, 2018 \\
\hline Keyword: \\
Energy analysis \\
Exergy analysis \\
Heat transfer \\
Nanofluids \\
Solar energy
\end{tabular}

\begin{abstract}
Photovoltaic thermal (PVT), which is the popular technology for harvesting solar energy, receive solar energy and convert it into electrical and thermal energy simultaneously. In this review, design, heat transfer, energy modelling and performance analysis of PVT systems are presented. Four types of PVT systems base on heat transfer medium; air-based PVT system, water-based PVT system, the combination of water/air-based PVT system, and nanofluid-based PVT system are presented. In addition, major finding on energy and exergy analysis of PVT systems are summarized.
\end{abstract}

Copyright $\odot 2018$ Institute of Advanced Engineering and Science. All rights reserved.

\section{Corresponding Author:}

Ahmad Fudholi,

Solar Energy Research Institute, Universiti Kebangsaan Malaysia,

43600 Bangi Selangor, Malaysia.

Email: a.fudholi@gmail.com

\section{INTRODUCTION}

The depletion of fossil fuels resources has revived the interest in renewable energy resource utilization [1]-[2]. As a result, various research and development (R\&D) activities have been conducted to identify reliable and economically feasible alternative sources of clean energy. The choices include solar, wind, wave, and geothermal energies. Among these energy types, solar energy, which is widely used in heating and cooling applications, is the popular source [3]. Solar energy converts to electric energy using photovoltaic (PV) technology. The cons of this PV cell are declining in efficiency conversion when temperature raised and only responsive to a portion of the solar spectrum. The low efficiency and high cost of PV cell brings the idea of PVT system. It is the integration or hybrid of PV panel with solar thermal collector. The advantage of PVT enhances the electrical energy produce, removes waste heat from PV panel and minimized the usable space. Moreover, solar energy will convert to thermal energy as stored in air or water. PVT builds up from glass cover, solar cell, encapsulated materials and collector attached at the back. In terms of physical structure applied, the module could be classified as flat plate, concentrated and building integrated types. The absorber functions to absorb heat and simultaneously cool down the PV panel. The collected heat will be in the form of fluids or nanofluids.

Recently, energy and exergy analysis for PVT systems were studied base on experimental and theoretical study. A theoretical approach (mathematical model) to predict outlet and PV temperatures of finned PVT air collector system was studied [4]. The overall performance of the PVT system can be evaluated based on the thermodynamic, environmental and economic impacts analysis. Energy-exergyeconomic-environmental analyses for different PVT array systems was studied [5]. In this review, thermodynamic analysis is focused involving Secondary Thermodynamic Law or known as exergy analysis. It has become an essential tool in the system design, analysis, and optimization of thermal systems [6-11]. 


\section{TYPES OF PVT SYSTEMS}

PVT is the popular technology of a solar energy technology. PVT system is a device designed to receive solar energy, convert it into electrical and thermal energy, which transfer the thermal energy to the fluid that flows into the collector. Fig. 1A shows a PVT consisting of a PV panel, insulation and frame. Accordingly, PVT consists of one or more cover (glass sheets) or a transparent material placed above an absorbing plate with air flowing around it. One way to enhance the collector's efficiency of PVT system is use heat transfer area through absorber with corrugated surfaces (Figs. 1B), finned absorber (Fig. 1C), and porous media (Fig. 1D). PVT system can be classified into four types base on heat transfer medium; airbased PVT system (Figs. 1A-D), water-based PVT system (Fig. 1E), the combination of water/air-based PVT system, and nanofluid-based PVT system (Fig. 1F). Fig. 2 shows schematic and photograph of combination of water/air-based PVT system.
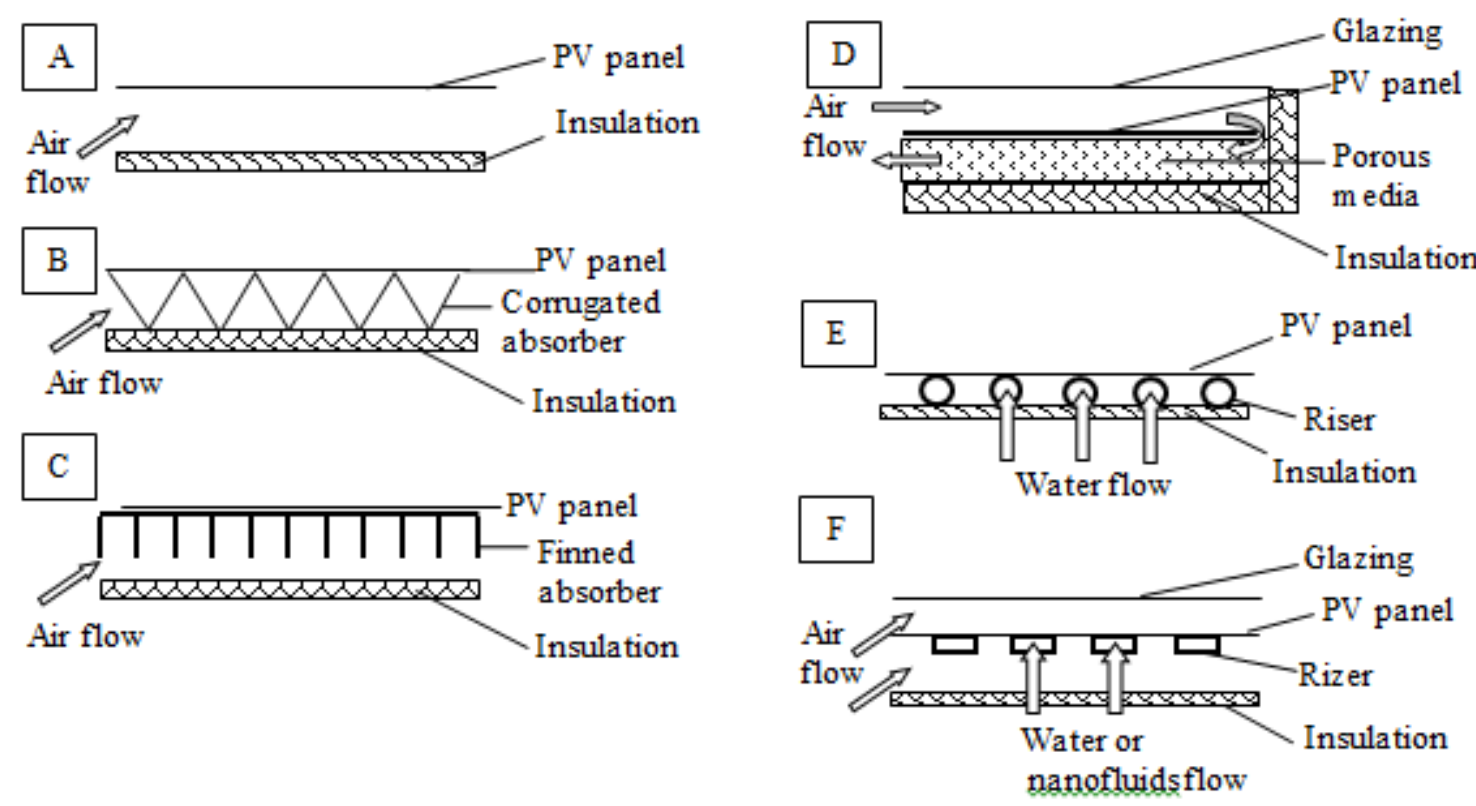

Figure 1. Various types of flat-plate PVT systems

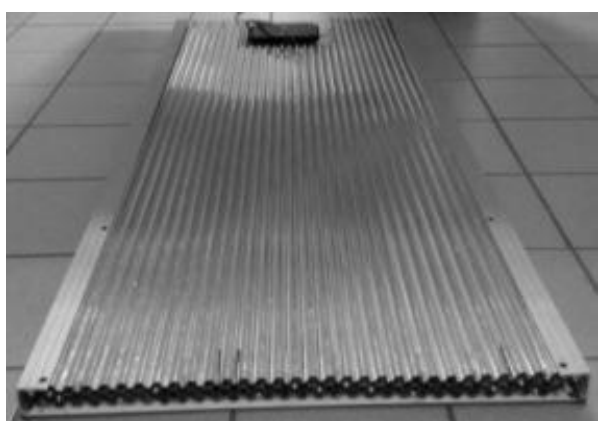

(a)

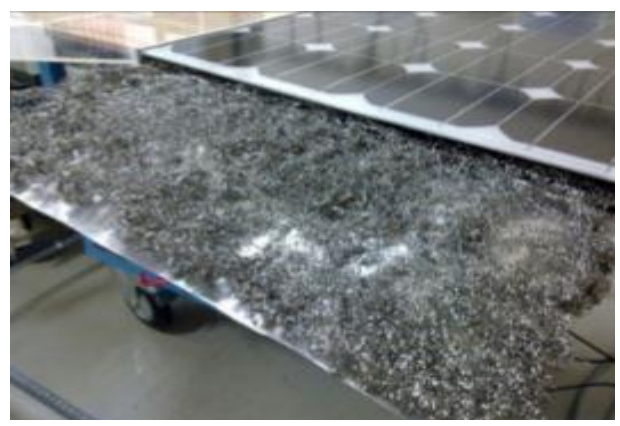

(b)

Figure 2. Photograph of (a) honeycomb absorber installed at the back of PV panel, (b) PVT air collector with stainless porous media [12] 


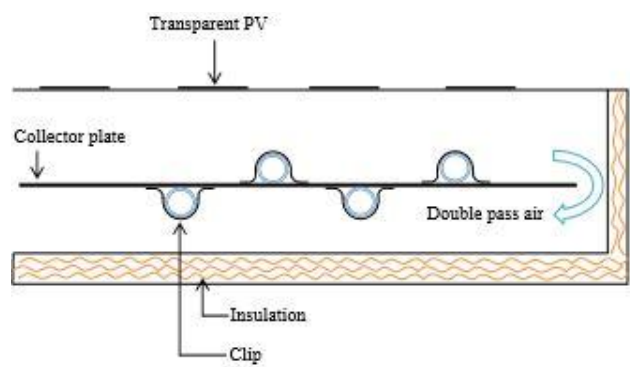

(a)

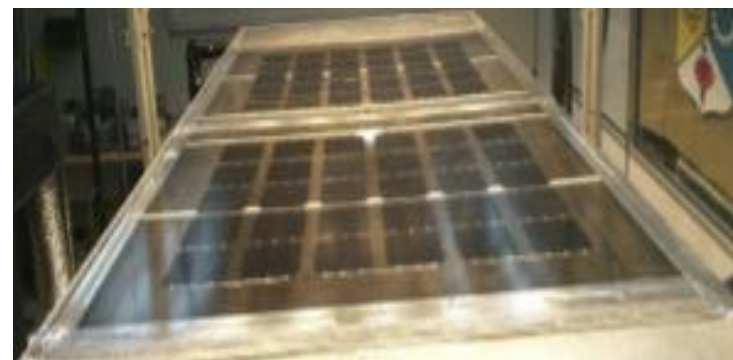

(b)

Figure 3. Combination of water/air-based PVT system; (a) schematic, (b) photograph [13]

\section{ENERGY AND EXERGY ANALYSIS OF PVT SYSTEMS}

The thermal efficiency of PVT system is a ratio of the useful thermal energy, $Q_{u}$ to the overall incidence irradiations, $I$.

$$
\eta_{t h}=\frac{Q_{u}}{I}
$$

The heat collected by the flat plate PVT collector can be measured by result of average mass flow rate, $\dot{m}$ heat capacity of flowing medium, $C_{p}$ and a temperature difference of the medium at the collector inlet, $t_{i}$ and outlet, $t_{o}[14-17]$.

$$
Q_{u}=\dot{\mathrm{m}} C_{p}\left(t_{o}-t_{i}\right)
$$

The electrical efficiency of PV, $\eta_{p v}$ is a function of temperature given by

$$
\eta_{p v}=\eta_{r}\left(1-\beta\left(T_{c}-T_{r}\right)\right)
$$

where $\eta_{r}$ is the reference efficiency of the PV, $\beta$ is the temperature coefficient $\left(\beta=0.0045^{\circ} \mathrm{C}\right), T_{c}$ and $T_{r}$ is cell temperature and the reference temperature [17].

Exergy is defined as the maximum amount of work that can be produced by a stream of matter, heat, or work as it reaches equilibrium with a reference environment. In the past few decades, exergy analysis has become an essential tool in thermal system design, analysis, and optimization [6-11]. If the effects of kinetic and potential energy changes are neglected, then the general exergy balance rate can be expressed in the following rate form:

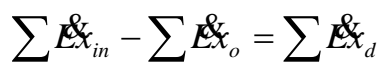

Or

$\sum E x_{i n}-\sum\left(E x_{t h}+E x_{P V}\right)=\sum E x_{d}$

where

$$
\begin{aligned}
& E x_{d}=E x_{\text {loss }}=E x_{\text {in }}-E x_{o} \\
& E x_{t h}=m C\left(T_{o}-T_{i}\right)\left(1-\frac{T_{a}+273}{T_{o}+273}\right) \\
& \& x_{P V}=\eta A_{c} S \\
& E x_{i n}=A_{c} N_{c} S\left[1-\frac{4}{3}\left(\frac{T_{a}}{T_{s}}\right)+\frac{1}{3}\left(\frac{T_{a}}{T_{s}}\right)^{4}\right]
\end{aligned}
$$


The exergy and exergy efficiency of PVT system is expressed as

$$
\stackrel{\&}{x_{P V T}}=\stackrel{\& x_{t h}}{ }+\stackrel{\&}{x_{P V}}
$$

$\eta_{e x}=\frac{E x_{o}}{E x_{i n}}$

Exergy analysis may be proposed using the sustainability index (SI). It can be expresed as [18]

$$
S I=\frac{1}{1-\eta_{E x}}
$$

Another performance of exergy analysis is improvement potential (IP). It is useful to the efficient analysis of processes or systems. The IP of a process or system is calculated by [19, 20]:

$$
I P=\left(1-\eta_{E x}\right) E x_{l o s s}
$$

where $\& x_{P V T}$ is the photovoltaic thermal exergy rate, $\&_{t h}$ is the thermal exergy rate, $\&_{i n}$ is the input exergy rate (radiation exergy rate), $E_{o}$ is the output exergy rate, $S$ is the solar radiation, $N_{c}$ is the collector's number, $A_{c}$ is the collector area, $T_{a}$ is the ambient temperature, and $T_{s}$ is the sun temperature ( $T_{s}$ $=5,777 \mathrm{~K})$.

Recently, Fudholi et al. [21] studied theoretical and experimental of PVT air collector with $\nabla$ groove, as shown in Table 1. They reported that PVT energy efficiencies were 31.21-94.24\%, and PVT exergy efficiencies of were $12.66-12.91 \%$. The PV and thermal efficiency was $9.87-11.34 \%$ and $21.3-82.9 \%$ respectively. Several studies on the energy and exergy analysis of PVT systems were reported as shown in Table 2. Salem et al. [22] studied exergy and energy analysis of hybrid PVT system using aluminium cooling plate. They reported that PVT exergy efficiencies of were 11.1-13.5\%, and PVT energy efficiencies were 59.3-92\%. The PV and thermal efficiency was $17.7-38.4 \%$ and 31.6-57.9\% respectively. Lari and Sahin [23] reported that PV energy efficiency was $13.2 \%$ for PVT nanofluid system. Khanjari et al. [24] reported that PV, thermal and PVT energy efficiencies was 10-13.7\%, 55\% and 90\% respectively, and PVT exergy efficiency was $15 \%$. Tripathi et al. [25] studied exergoeconomic and enviroeconomic analysis base on energy and exergy for PVT concentrating collector. They reported that thermal and PVT energy efficiencies were 40-50\% and 45-63\%, respectively. Singh et al. [26] studied energy and exergy for active solar still integrated with two hybrid PVT collectors. They reported that thermal and PVT energy efficiencies was 69.06\% and 75\%, respectively. Energy and exergy analyses for PVT air collectors were studied [27, 28]. Hazami et al. [27] and Gholampour and Ameri [28] reported that PVT exergy efficiency was $14.8 \%$ and $8.66 \%$, respectively. Exergoeconomic and environmental analyses for PVT mixed mode greenhouse solar dryer was studied [29]. They reported that PVT energy efficiency was $68.5 \%$. Exergoeconomicenviroeconomic--environmental-exergy-energy analyses were studied for active solar distillation system [32] in 2015 .

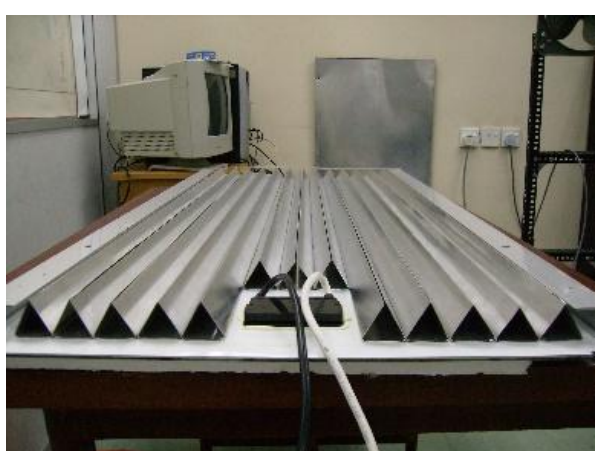

(a)

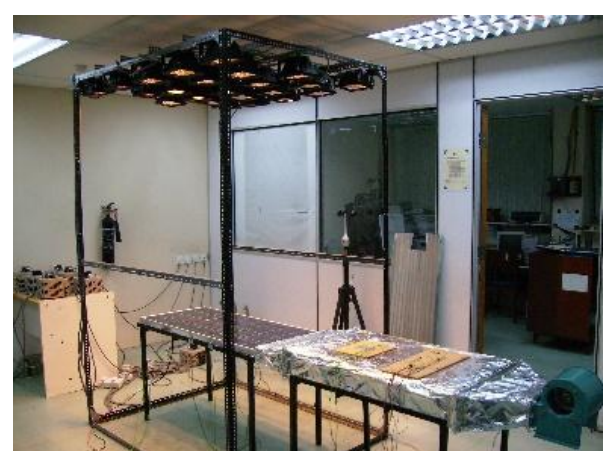

(b)

Figure 4. Photograph of (a) PVT collector with $\nabla$-groove, (b) PVT collector under solar simulator 
Tables 1. Schematic diagram of heat transfer characteristics and mathematical model of PVT air collector with $\nabla$-groove

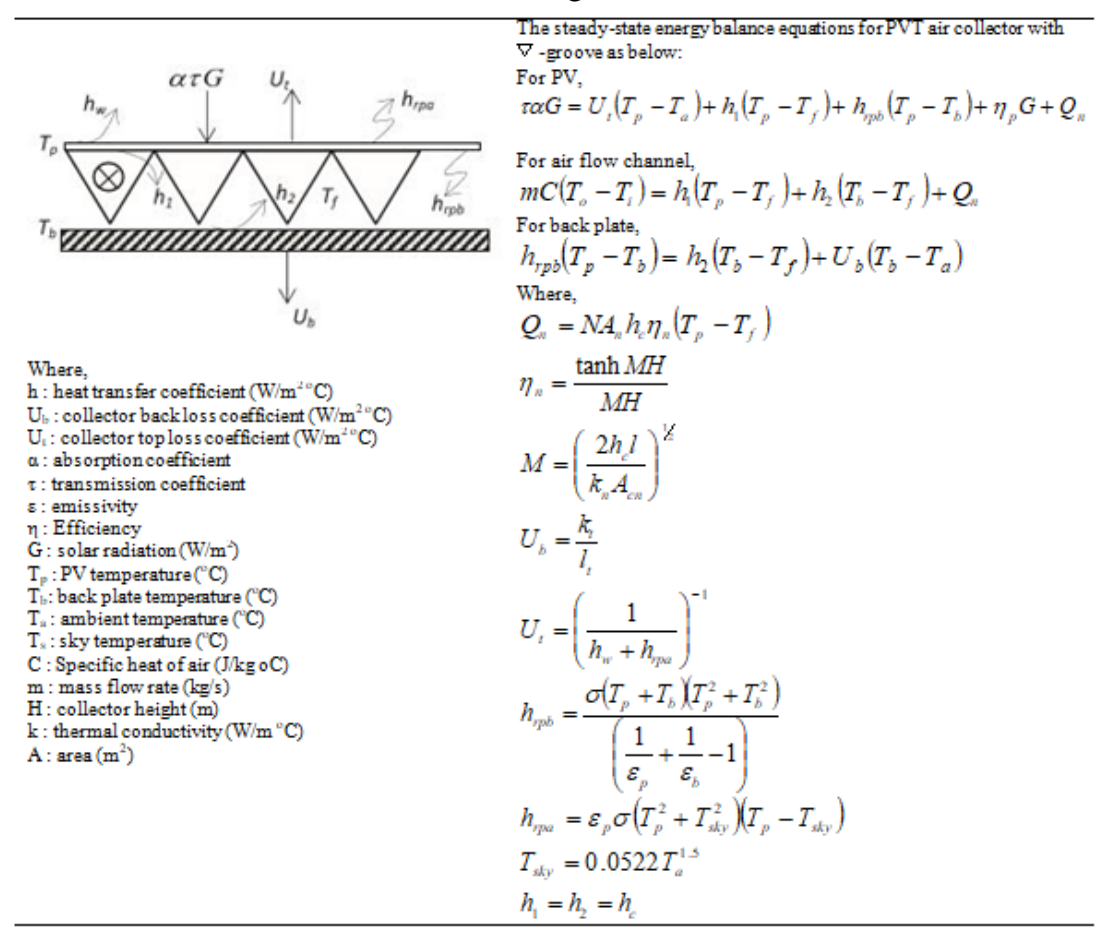

Tables 2. The studies conducted of PVT systems

\begin{tabular}{|c|c|c|c|c|c|c|}
\hline \multirow[t]{2}{*}{ Year } & \multirow[t]{2}{*}{ Author(s) } & \multirow[t]{2}{*}{ PVT systems } & \multicolumn{3}{|c|}{ Energy efficiency (\%) } & \multirow{2}{*}{$\begin{array}{l}\text { PVT } \\
\text { Exergy } \\
\text { efficiency }\end{array}$} \\
\hline & & & pVT & pV & Thernal & \\
\hline 2018 & Fudholi et al. [21] & PVT air collector with $\nabla$-groove & & $\begin{array}{l}9.87- \\
1134\end{array}$ & $213-829$ & $12.66-12.91$ \\
\hline 2017 & Salem [22] & Hybrid PVT system & $593-92$ & $\begin{array}{l}17.7- \\
38.4\end{array}$ & $31.6-579$ & $11.1-13.5$ \\
\hline 2017 & Lari \& Sahin [23] & PVT nanofluid system & NA & 132 & NA & NA \\
\hline 2016 & Khanjari [24] & PVT nanofluid system & 90 & $10-13.7$ & 55 & 15 \\
\hline 2016 & Tripathi et al. [25] & PVT concentrating collector & $45-63$ & NA & $40-50$ & NA \\
\hline 2016 & Singet al. [26] & $\begin{array}{l}\text { Active solar still integrated with two } \\
\text { hybrid PVT collectors }\end{array}$ & 69.06 & NA & 75 & NA \\
\hline 2016 & Hazami et al. [27] & PVT air collector system & NA & 15 & 50 & 14.8 \\
\hline 2016 & $\begin{array}{l}\text { Gholampour \& Ameri } \\
\text { [28] }\end{array}$ & PVT flat transpired air collectors & 55 & NA & 6991 & 8.66 \\
\hline 2016 & Tiwari \& Tiwari [29] & PVT mixed mode greenhouse solar dryer & 68.5 & NA & NA & NA \\
\hline 2015 & Rajoria et al. [30] & Semitransparent PVT air collector & NA & $3.1-9.1$ & $12.1-28.1$ & NA \\
\hline 2015 & Jahromi et al. [31] & $\begin{array}{l}\text { Commercially available PVT water } \\
\text { collector }\end{array}$ & NA & $7.5-8.7$ & $51.6-52$ & $9.6-9.7$ \\
\hline 2015 & Tiwari et al. [32] & $\begin{array}{l}\text { PV flat plate collector active solar } \\
\text { distillation system }\end{array}$ & $\begin{array}{l}28.5- \\
53.4\end{array}$ & NA & $13.4-232$ & NA \\
\hline 2014 & Tbrahim et al [33] & PVT water collector & $55-62$ & 11.4 & $45-51$ & $12.0-14.0$ \\
\hline 2014 & $\begin{array}{l}\text { Kamthania \& Tiwari } \\
{[34]}\end{array}$ & $\begin{array}{l}\text { Semi-transparent hybrid PVT double } \\
\text { pass facade }\end{array}$ & NA & 12 & NA & NA \\
\hline 2013 & Rajoria et al. [35] & Novel hybrid PVT air collector & 113 & NA & NA & 163 \\
\hline 2013 & Mishra \& Tiwari [36] & Hybrid PVT water collector & NA & $\begin{array}{l}10.0- \\
10.4\end{array}$ & $28.2-459$ & NA \\
\hline 2012 & Agrawal et al [37] & Glazed hybrid PVT tiles air collector & NA & 12.4 & 35.7 & NA \\
\hline 2011 & Gang et al. [38] & Heat pipe PVT system & NA & 9.4 & 419 & 6.8 \\
\hline 2011 & Agrawal \& Tiwari [39] & Hybrid micro-channel PVT air collector & NA & NA & NA & $9.38-18.03$ \\
\hline 2011 & Wu et al. [40] & Heat pipe PVT hybrid system & NA & 8.45 & 63.65 & 10.26 \\
\hline 2010 & Sarhaddi et al. [41] & PVT air collector & 45 & 10 & 17.18 & 10.75 \\
\hline 2010 & Agrawal \& Tiwari [42] & BIPVT systems & $\mathrm{NA}$ & 7.13 & 33.54 & NA \\
\hline 2010 & Agrawal \& Tiwari [43] & BIPVT systems & 53.7 & NA & NA & NA \\
\hline
\end{tabular}




\section{CONCLUSION}

Based on the present review, the following conclusions can be drawn; 1) A number of research have been done on PVT systems over the last four decades, exploring aspects such as efficiency enhancements by design development, numerical simulation, prototype design, experimental testing and testing methodologies for PVT systems, 2) The development of PVT system is a very promising area of research. Today, PVT systems using in various applications, such as solar drying, solar cooling, water heating, desalination, and pool heating.

\section{ACKNOWLEDGEMENTS}

The authors would like to thank the UKM for funding (GP-K020448) and (GGP-2017-045).

\section{REFERENCES}

[1] Palanisamy R, Vijayakumar K. "Wind-PV hybrid energy source fed three level NPC with quasi Z source network,"International Journal of Power Electronics and Drive Systems (IJPEDS), vol. 8, no. 3. pp. 1285-93, 2017.

[2] A.R. Bhatti, et al." A comprehensive overview of electric vehicle charging using renewable energy,"International Journal of Power Electronics and Drive Systems (IJPEDS), vol. 7, no. 1. pp. 114-23, 2016.

[3] A. Fudholi, K. Sopian. "Review on exergy and energy analysis of solar air heater,"International Journal of Power Electronics and Drive Systems (IJPEDS), vol. 9, no. 1. 2018. http://doi.org/10.11591/ijpeds.v9.i1.pp\%25p

[4] M. Zohri, et al.,"Photovoltaic Thermal (PVT) System with and without Fins Collector: Theoretical Approach, "International Journal of Power Electronics and Drive System, vol. 8, No. 4, pp. 1756-63, 2017.

[5] C.S. Rajoria, et al., "A newer approach on cash flow diagram to investigate the effect of energy payback time and earned carbon credits on life cycle cost of different photovoltaic thermal array systems," Solar Energy, vol. 124, pp. 254-67, 2016.

[6] A. Fudholi, et al., "Energy and exergy analyses of solar drying system for red seaweed," Energy and Buildings, vol. 68, pp. 121-29, 2014.

[7] A. Fudholi, et al., "Performances and improvement potential of solar drying system for palm oil fronds,"Renewable Energy, vol. 78, pp. 561-65, 2015.

[8] A. Fudholi, et al., "Performance analysis of solar drying system for red chili," Solar Energy, vol. 99, pp. 47-54, 2014.

[9] A. Fudholi, et al., "Energy analysis and improvement potential of finned double-pass solar collector," Energy Conversion and Management, vol. 75, pp. 234-40, 2013.

[10] M. Yahya, et al., "Energy and exergy analyses of solar-assisted fluidized bed drying integrated with biomass furnace,"Renewable Energy, vol. 105, pp. 22-29, 2017.

[11] S.A. Kalogirou, et al., "Exergy analysis on solar thermal systems: a better understanding of their sustainability,"Renewable Energy, vol. 85, pp. 1328-33, 2016.

[12] M.Y. Othman, et al., "Performance study of air-based photovoltaic-thermal (PV/T) collector with different designs of heat exchanger,"Sains Malaysiana, vol. 42, No.9, pp. 1319-25, 2013.

[13] M.Y. Othman, et al., "Performance analysis of PV/T combi with water and air heating system: an experimental study,"Renewable Energy, vol. 86, pp. 716-22, 2016.

[14] A. Fudholi, et al., "Performance and cost benefits analysis of double-pass solar collector with and without fins," Energy Conversion and Management, vol. 76, pp. 8-19, 2013.

[15] A. Fudholi, et al., "Collector efficiency of the double-pass solar air collectors with fins," Proceedings of the 9th WSEAS International Conference on SYSTEM SCIENCE and SIMULATION in ENGINEERING (ICOSSSE'10), Japan, 2010, pp. 428-34.

[16] A. Fudholi, et al., " Experimental Study of the double-pass solar air collector with staggered fins," Proceedings of the 9th WSEAS International Conference on SYSTEM SCIENCE and SIMULATION in ENGINEERING (ICOSSSE'10), Japan, 2010, pp. 410-14.

[17] A. Fudholi, et al., "Performance analysis of photovoltaic thermal (PVT) water collectors,"Energy Conversion and Management, vol. 78, pp. 641-651, 2014.

[18] H. Caliskan, "Energy, exergy, environmental, enviroeconomic, exergoenvironmental (EXEN) and exergoenviroeconomic (EXENNEC) analyses of solar collectors," Renewable and Sustainable Energy Review, vol. 69, pp. 488-492, 2017.

[19] A. Fudholi, et al., "Review of solar drying systems with air-based solar collectors in Malaysia," Renewable and Sustainable Energy Review, vol. 51, pp. 1191-1204, 2015.

[20] A. Fudholi, et al., "Techno-economic of solar drying systems with water based solar collectors in Malaysia: a review," Renewable and Sustainable Energy Review, vol. 51, pp. 809-820, 2015.

[21] A. Fudholi, et al., "Energy and exergy analyses of photovoltaic thermal collector with $\nabla$-groove," Solar Energy, vol. 159 , pp. 742-50, 2018.

[22] M.R. Salem, et al., " Experimental investigation of the performance of a hybrid photovoltaic/thermal solar system using aluminium cooling plate with straight and helical channels," Solar Energy, vol. 157, pp. 147-56, 2017. 
[23] M.O. Lari \& A.Z. Sahin, "Design, performance and economic analysis of a nanofluid-based photovoltaic/thermal system for residential applications," Energy Conversion and Management, vol. 149, pp. 467-84, 2017.

[24] Y. Khanjari, et al., "Numerical investigation on using of nanofluid in a water-cooled photovoltaic thermal system," Energy Conversion and Management, vol. 122, pp. 263-78, 2016.

[25] R. Tripathi, et al., "Overall energy, exergy and carbon credit analysis of N partially covered Photovoltaic Thermal (PVT) concentrating collector connected in series," Solar Energy, vol. 136, pp. 260-67, 2016.

[26] D.B. Singh, et al., "Experimental studies of active solar still integrated with two hybrid PVT collectors,"Solar Energy, vol. 130, pp. 207-23, 2016.

[27] M. Hazami, et al., " Energetic and exergetic performances analysis of a PV/T (photovoltaic thermal) solar system tested and simulated under to Tunisian (North Africa) climatic conditions,"Energy, vol. 107, pp. 78-94, 2016.

[28] M. Gholampour \& M. Ameri,"Energy and exergy analyses of Photovoltaic/Thermal flat transpired collectors: Experimental and theoretical study,"Applied Energy, vol. 164, pp. 837-56, 2016.

[29] S. Tiwari \& G.N. Tiwari, "Exergoeconomic analysis of photovoltaic-thermal (PVT) mixed mode greenhouse solar dryer,"Energy, vol. 114, pp. 155-64, 2016.

[30] C.S. Rajoria, et al., "Exergetic and enviroeconomic analysis of semitransparent PVT array based on optimum air flow configuration and its comparative study,"Solar Energy, vol. 122, pp. 1138-45, 2015.

[31] S. N. Jahromi, et al., "Exergy and economic evaluation of a commercially available PV/T collector for different climates in Iran,"Solar Energy Procedia, vol. 75, pp. 444-56, 2015.

[32] G.N. Tiwari, et al., "Exergoeconomic and enviroeconomic analyses of partially covered photovoltaic flat plate collector active solar distillation system,"Desalination, vol. 367, pp. 186-96, 2015.

[33] A. Ibrahim et al., "Efficiencies and improvement potential of building integrated photovoltaic thermal (BIPVT) system," Energy Conversion and Management, vol. 77, pp. 527-34, 2014.

[34] D. Kamthania \& G.N. Tiwari, "Energy metrics analysis of semi-transparent hybrid PVT double pass facade considering various silicon and non-silicon based PV module Hyphen is accepted,"Solar Energy, vol. 100, pp. 12440, 2014.

[35] C.S. Rajoria, et al., "Exergetic and enviroeconomic analysis of novel hybrid PVT array, "Solar Energy, vol. 88, pp. 110-19, 2013.

[36] R.K. Mishra \& G.N. Tiwari, "Energy and exergy analysis of hybrid photovoltaic thermal water collector for constant collection temperature mode,"Solar Energy, vol. 90, pp. 58-67, 2013.

[37] S. Agrawal, et al., "Indoor experimental analysis of glazed hybrid photovoltaic thermal tiles air collector connected in series,"Energy and Buildings, vol. 53, pp. 145-51, 2012.

[38] P. Gang, et al., "A numerical and experimental study on a heat pipe PV/T system, "Solar Energy, vol. 85, pp. 911$21,2011$.

[39] S. Agrawal \& G.N. Tiwari, "Energy and exergy analysis of hybrid micro-channel photovoltaic thermal module,"Solar Energy, vol. 85, pp. 356-70, 2011.

[40] S.Y. Wu, et al., "A heat pipe photovoltaic/thermal (PV/T) hybrid system and its performance evaluation,"Energy and Buildings, vol. 43, pp. 3558-57, 2011.

[41] F. Sarhaddi, et al., "Behzadmehr, Exergetic performance assessment of a solar photovoltaic thermal (PV/T) air collector,"Energy and Buildings, vol. 42, pp. 2184-99, 2010.

[42] B. Agrawal \& G.N. Tiwari, "Life cycle cost assessment of building integrated photovoltaic thermal (BIPVT) systems,"Energy and Buildings, vol. 42, pp. 1472-81, 2010.

[43] B. Agrawal \& G.N. Tiwari,"Optimizing the energy and exergy of building integrated photovoltaic thermal (BIPVT) systems under cold climatic conditions,"Applied Energy, vol. 87, pp. 417-26, 2010.

\section{BIOGRAPHIES OF AUTHORS}

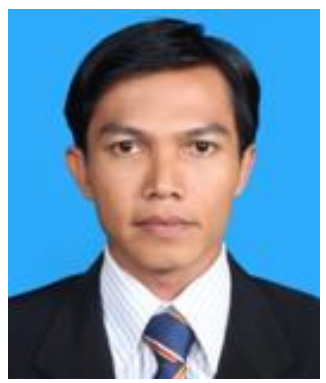

Ahmad Fudholi, Ph.D, M.Sc obtained his S.Si (2002) in physics. He was born in 1980 in Indonesia, and has working experience about 4 years (2004-2008) as Head of Physics Department at Rab University Pekanbaru, Riau, Indonesia. A. Fudholi started his master course in Energy Technology (2005-2007) at Universiti Kebangsaan Malaysia (UKM). After his master he became Research Assistant at UKM up to 2012. After his Ph.D (2012) in renewable energy, he became Postdoctoral in Solar Energy Research Institute (SERI) UKM up to 2013. He joined the SERI as a Lecture in 2014. More than USD 310,000 research grant (13 grant/ project) in 2014-2017 was involved. More than 25 M.Sc project supervised and completed. Until now, he managed to supervise $5 \mathrm{Ph} . \mathrm{D}$ (4 main supervisor and 1 Co. supervisor), 3 Master's student by research mode, and 5 Master's student by coursework mode, he was also as examiner ( $3 \mathrm{Ph} . \mathrm{D}$ and 1 M.Sc). His current research focuses on renewable energy, especially solar energy technology, micropower system, solar drying systems, and advanced solar thermal systems (solar assisted drying, solar heat pump, PVT systems). He has published more than 100 peer-reviewed papers, which 25 papers in ISI index (20 Q1, impact factor more than 3 ) and more than 50 papers in Scopus index, 16 more currently accepted manuscript, 20 more currently under review, and 2 book chapters. Addition, he has published more than 70 papers in international conferences. His total citations of 609 by 419 documents and h-index of 12 in Scopus (Author ID: 57195432490). His total citations of 1132 and h-index of 19 in google scholar. He is appointed as reviewer of high impact (Q1) journal such as Renewable and Sustainable Energy Reviews, Energy 
Conversion and Management, Applied Energy, Energy and Buildings, Applied Thermal Engineering, Energy, Industrial Crops and Products, etc. He is appointed as reviewer of reputation journals such as Drying Technology, International Journal of Green Energy, Biosystem Engineering, Journal of Sustainability Science and Management, Journal of Energy Efficiency, Sains Malaysiana, Jurnal Teknologi etc. He is also appointed as editor journals. He has received several awards such as Gold Medal Award at the International Ibn Al-Haytham's Al-Manazir Innovation and Invention Exhibition 2011, Silver Medal Award at the International Technology EXPO (ITEX) 2012, Silver Medal Award at the Malaysia Technology Expo (MTE) 2013, Bronze Medal Award at International Exposition of Research and Invention (PECIPTA) 2011, also 2 Bronze Medal Award at PECIPTA 2017. He was also invited as speaker: Workshop of Scientific Journal Writing; Writing Scientific Papers Steps Towards Successful Publish in High Impact (Q1) Journals.

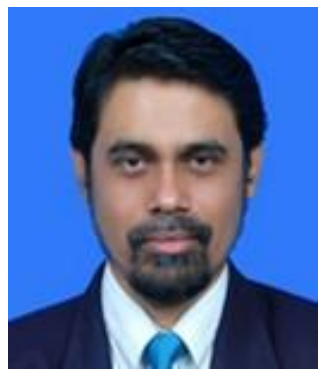

Prof Dato' Dr. Kamaruzzaman Sopian graduated with the BS Mechanical Engineering from the University of Wisconsin-Madison in 1985, the MS in Energy Resources University of Pittsburgh in 1989 and PhD in Mechanical Engineering from the Dorgan Solar Laboratory, University of Miami at Coral Gables in 1997. He was promoted to the post of Professor of Renewable Energy in the Department of Mechanical and Material Engineering, at the UKM Malaysia in 2001 and currently is the Director of the Solar Energy Research Institute in the same university since 2005 . He has been involved in the field of renewable energy for more than 25years. His main contributions are in solar radiation modeling and resource assessment, advanced solar photovoltaic systems and advanced solar thermal systems. He has secure research funding from the Malaysian Minstry of Science and Malaysian Ministry of Education and industry for more than USD 6 million. He has conducted renewable enery courses the Asian School of Energy (2007-2014) funded by ISESCO, COMSAT, TIKA and UNESCO. He has published over 800 research papers in journals and conferences (SCOPUS h index $=49$, no. of citation $=$ 8001) (Google Scholar h index $=60$, no. of citation $=13473$ ). A total of 32 MSc (coursework), $15 \mathrm{MSc}$ (research mode) and $50 \mathrm{PhD}$ candidates from various countries. He has undertaken short assignments in about 10 countries for international agencies and programs such as UNDP-GEF, UNIDO, ASEAN EU-Energy Facility, ASEAN-Australia Economic Co-operation Program, ASEAN-CIDA, JSPS-VCC, British Council CHICHE, ISESCO and UNESCO related to renewable energy technology. He has been appointed as the Honorary Professor of Renewable Energy, at University of Nottingham, United Kingdom (2009-2013). In addition, he has been appointed as the associate editors in high impact journals. He won several international awards for his academic contribution in renewable energy including the IDB (Islamic Development Bank) S\&T Prize 2013, World Renewable Energy Network Pioneer Award 2012, Malaysia Green Technology Award 2012, and the ASEAN Energy Awards (2005, 2007, 2013 and 2014). He has 4 patents, 20 patents pending, 6 copyrights, and 1 trademark for his innovation in renewable energy technology. The innovation and invention in renewable energy technology have won 80 medals in national and international innovation and invention competitions including special innovation awards such as Prix de L 'Environnement by the Swiss Society for Environmental Protection, 2001, Geneva, Sustainable Development Award INNOVA 2007, Special Prize, Korea Invention Promotion Association at the INPEX Pittsburgh 2008 and Energy and Environmental Award, at INNOVA 2013 in Brussels. His Royal Highness The Sultan of Perak conferred the Paduka Mahkota Perak and the Dato' Paduka Mahkota Perak in 2013. He was conferred as a Fellow of the Malaysia Academy of Sciences (FASc) in 2011. 